\title{
Penggunaan alat sablon manual untuk meningkatkan keterampilan berbicara dengan membuat media gambar fauna styrofoam siswa tunagrahita
}

\author{
Eko Julianto Wibowo \\ Sekolah Luar Biasa Negeri 1 Kota Blitar. \\ E-mail: ekojuliantow@gmail.com, Telp: +6285649120216
}

\begin{abstract}
Abstrak: Tujuan penelitian ini adalah (1) Mengetahui penggunaan atau peran media gambar gambar fauna styrofoam dalam hal meningkatkan keterampilan berbicara siswa tunagrahita kelas VIII C1 di SLBN 1 Kota Blitar. (2) Meningkatkan keterampilan berbicara siswa tunagrahita kelas VIII C1 di SLBN 1 Kota Blitar. Jenis penelitian yang digunakan adalah penelitian tindakan kelas (PTK) dengan menerapkan media gambar styrofoam pada pembelajaran Bahasa Indonesia. Subjek penelitian sebanyak 3 siswa kelas VIII C1 di SLBN 1 kota Blitar pada Semester I tahun pembelajaran 2019/2020. Metode yang digunakan dalam penelitian adalah teknik tes dan non tes. Teknik analisis data yang digunakan adalah keterpercayaan, dan keterpahaman. Dalam menguji keabsahan data dilakukan dengan cara reduksi data, penyajian data, dan penarikan kesimpulan. Hasil penelitian menunjukkan bahwa penerapan media gambar styrofoam pada pembelajaran Bahasa Indonesia dapat meningkatkan keterampilan berbicara siswa tunagrahita kelas VIII C1 di SLBN 1 Kota Blitar dalam mendeskripsikan mengenal fauna. Bukti dari peningkatan kemampuan siswa tersebut dapat dilihat pada peningkatan nilai rata-rata siswa dalam belajar yaitu pada kondisi awal diperoleh rata-rata 31,33, pada siklus I diperoleh rata-rata 70,65 dan pada siklus II diperoleh rata-rata 81,66 yang berarti ada peningkatan keterampilan berbicara siswa dalam belajar.
\end{abstract}

Kata kunci: Keterampilan berbicara, Media gambar fauna styrofoam, siswa tunagrahita.

\section{The usage of manual silk-screening tools to enhance speech skill by making fauna picture of Styrofoam media to mentally retardation students}

\begin{abstract}
The purposes of this research were (1) to know the usage or role of fauna pictures of Styrofoam media in the case of enhancing the speech skill of mentally retardation students class VIII C1 in SLBN 1 Blitar city, and (2) to enhance the speech skill of mentally retardation students class VIII C1 in SLBN 1 Blitar city. The research kind used was class treatment by applying Styrofoam picture media in learning Indonesian. The research subjects were 3 students of class VIII C1 in SLBN 1 Blitar city in the first semester of academic year 2019-2020. The methods used in this research were test and non test techniques. The techniques of data analysis used were trusting and understanding. The testing of data validity was done by data reduction, data presentation, and taking conclusion. The research result indicated that the application of Styrofoam picture media in learning Indonesian could enhance the speech skill of mentally retardation students class VIII C1 in SLBN 1 Blitar city in describing fauna recognizing. The proof of the students' ability enhancement could be seen on the students' average value in learning i.e. in the early condition it was obtained 31,33 in average, in cycle 1 it was obtained 70,65 in average, and in cycle 2 it was obtained 81,66 in average which meant that there was enhancement of the students' speech skill in learning.
\end{abstract}

Keywords: Speech skill, Styrofoam fauna picture media, mentally retardation students.

\section{PENDAHULUAN}

Salah satu keterampilan berbahasa siswa dan kecakapan hidup berbasis seni dan teknologi berbasis ekonomis yang harus dikuasai siswa kelas VIII Tunagrahita adalah mampu berbicara dalam pembuatan karya seni. Salah satu bentuk berbicara yang populer di kalangan anak-anak adalah bercerita. Mengingat bahwa siswa kelas VIII Tunagrahita merupakan siswa yang termasuk siswa kelas tinggi di tingkat Sekolah Menengah Pertama, mestinya mereka telah mampu bercerita secara lisan maupun tertulis dan membuat hasil karya. Namun pada kenyataannya masih banyak siswa yang belum mampu bercerita dalam membuat hasil karyanya dengan baik. 
Siswa merupakan subjek dalam dunia pendidikan dan guru merupakan ujung tombak dari dunia pendidikan. Sebagai subjek belajar, siswa mempunyai karakteristik sendiri dimana karakteristik antara siswa yang satu dengan siswa lain sangat berbeda-beda. Terdapat siswa yang memiliki tingkat intelegensi yang tinggi sehingga cepat menangkap penjelasan guru ada juga siswa dengan intelegensi yang rendah sehingga mengalami kesulitan dalam menerima pelajaran. Kesulitan dalam menerima materi pelajaran tersebut dialami oleh siswa kelas VIII Tunagrahita di SLBN 1 kota Blitar yang memiliki tingkat intelegensi rendah karena termasuk siswa dengan keterbatasan atau penyandang tunagrahita sehingga lambat dalam menangkap pelajaran yang diberikan oleh guru dan mengalami kesulitan dalam memahami mata pelajaran yang diberikan oleh guru, salah satunya adalah mata pelajaran Bahasa Indonesia Tema 1 Temanku Sahabatku pada pembelajaran ke 1 terpadu dengan mata pelajaran PPKn, IPA dan SBdP. Tema 1 Pembelajaran ke 1 fokus pada pembahasan materi mengenal gambar fauna.

Pada pembelajaran ini siswa ada kegiatan Prakarya dalam membuat karya seni media gambar fauna yang sangat bermanfaat untuk keterampilan berbahasa dan kecakapan hidup setiap siswa dan berkaitan kerjasama dengan guru dan temannya, Sikap kerjasama merupakan hal yang sangat penting dalam menjalani hubungan dengan sesama.

Media pembelajaran yang umum digunakan oleh guru dalam menyampaikan materi sebelum penelitian ini dilakukan hanya dengan media gambar pada buku paket, koran, majalah dan guru berceramah saja sesuai dengan materi.

Dengan hanya media gambar pada buku paket dan penugasan yang diterapkan oleh guru menemui permasalahan diantaranya; (1) Ketika pembelajaran berlangsung, anak hanya diam, terkadang menundukkan kepala dengan pandangan kosong tanpa memperhatikan guru ketika memberikan materi; (2) Ketika siswa diajak berbicara dan diberikan pertanyaan menggunakan bahasa Indonesia oleh guru, siswa mengerti maksud dari pertanyaan yang disampaikan dan siswa dapat memberikan jawaban sesuai dengan konteks pertanyaan yang diberikan menggunakan bahasa Indonesia, namun jawaban-jawaban selanjutnya sering menggunakan bahasa daerah siswa; (3) Media yang disajikan kurang menarik sehingga siswa kurang termotivasi untuk mempelajari materi; (4) Siswa juga belum dapat mengajukan pertanyaan mengenai materi pembelajaran sehingga siswa hanya mengikuti instruksi yang guru berikan; (5) Pemahaman siswa dalam berbahasa Indonesia masih kurang, karena dalam pembelajarannya hampir semua pesan yang diinstruksikan ke siswa harus diterjemahkan ke dalam bahasa Jawa, sehingga guru harus mengulang beberapa kali dalam penyampaian pembelajaran yang disampaikan yang berakibat pada rendahnya hasil belajar yang diperoleh siswa. Melihat kelemahan dari media gambar pada buku paket maka dalam penelitian tindakan kelas ini disampaikan alternatif media pembelajaran baru yang diharapkan dapat mengatasi kesulitan siswa dalam memahami materi gambar fauna. Salah satu media pembelajaran yang diterapkan oleh guru pada penelitian tindakan kelas ini adalah media gambar fauna pada styrofoam yang dibuat menggunakan alat bantu sablon manual. Dengan media ini pembelajaran menjadi lebih menarik dan mampu membuat seluruh siswa terlibat dalam suasana pembelajaran sehingga diharapkan mampu meningkatkan kemampuan berbahasa siswa dalam konsep gambar fauna dan diperoleh hasil belajar yang sesuai dan diharapkan serta hasil karya seni media gambar fauna pada styrofoam ini dapat dijual di dalam sekolah sendiri, sekolah lain atau disekitar lingkungan yang nantinya menghasilkan pendapatan unuk para siswa.

\section{METODE}

Jenis penelitian ini adalah penelitian tindakan kelas atau yang sering dikenal dengan istilah PTK, yaitu merupakan suatu upaya dari pendidik untuk meningkatkan atau memperbaiki proses belajar mengajar ke arah tercapainya tujuan pendidikan atau pengajaran itu sendiri. Masalah penelitiannya bersumber dari lingkungan kelas yang dirasakan sendiri oleh pendidik untuk diperbaiki, dievaluasi dan akhirnya dibuat suatu keputusan sebagai solusi dan dilaksanakan suatu tindakan untuk memecahkan masalah dalam pembelajaran tersebut (Zulkarnaeni, 2005:1). Model penelitian tindakan kelas yang digunakan adalah model penelitian yang dikembangkan oleh Kemmis dan taggart (Mc. Niff, 1992: 26-28). Pada hakikatnya model ini berupa perangkat-perangkat atau untaian-untaian dengan satu perangkat terdiri dari empat komponen, yaitu perencanaan, tindakan, pengamatan, refleksi. Keempat komponen yang berupa untaian tersebut dipandang sebagai satu siklus. Oleh karena 
itu, pengertian siklus pada kesempatan ini adalah suatu putaran kegiatan yang terdiri dari perencanaan, tindakan, observasi, dan refleksi.

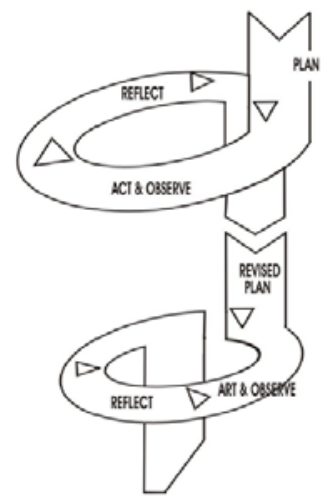

Gambar 1. Model Penelitian Tindakan Kemmis dan Mc. Taggart

(Mc. Niff, 1992: 26-28)

Lokasi dan Waktu Penelitian ini dilaksanakan di SLBN 1 kota Blitar, yang beralamat di Jl. Cibareno No. 39, kecamatan Kepanjenkidul Kota Blitar pada siswa tunagrahita kelas VIII C1 semester I tahun pembelajaran 2019/2020 yaitu pada bulan Agustus sampai dengan Oktober 2019.

Subjek dalam penelitian ini adalah siswa tunagrahita kelas VIIIC1 di SLBN 1 Kota Blitar pada Semester I tahun pembelajaran 2019/2020 yang berjumlah 3 orang siswa 1 laki-laki dan 2 perempuan. Subjek Penelitian merupakan kajian utama dalam penelitian ini. Penelitian ini bersifat kualitatif sehingga keberadaan subjek dirasa sangat penting.

Teknik dan Alat Pengumpulan Data Berdasarkan jenis penelitian yang digunakan, penelitian kualitatif memandang bahwa manusia adalah instrumen utama dalam mengumpulkan data, dengan alasan bahwa manusia memiliki kemampuan menyesuaikan diri dengan berbagai situasi dan ragam realistis. Selain itu manusia memiliki sifat respoden, adaptif dan holistik, dapat membangun, pengertian dari pengetahuan yang tidak terkatakan, mampu mengolah, mengejar klarifikasi dan mampu meningkatkan pemahaman yang lebih dalam. Teknik dan alat pengumpulan data dalam penelitian ini meliputi teknik tes dan non tes. Teknik tersebut dapat dijelaskan sebagai berikut : Tes merupakan sejumlah pertanyaan yang memiliki jawaban benar atau salah (Mardapi, 2004:71). Teknik tes merupakan alat prosedur yang digunakan untuk mengetahui atau mengukur sesuatu dalam suasana, dengan cara dan aturan-aturan yang sudah ditetapkan (Arikunto, 1990:51). Tes yang dilakukan dalam penelitian ini berupa tes tertulis yang diberikan kepada siswa untuk mengidentifikasi kekurangan atau kelemahan siswa dalam berbicara dan setiap akhir siklus untuk mengetahui peningkatan mutu hasil yang diperoleh siswa. Teknik non tes yang digunakan dalam penelitian ini adalah melalui observasi, wawancara serta dokumentasi. Observasi (observation) atau pengamatan merupakan suatu teknik mengumpulkan data dengan jalan mengadakan pengamatan terhadap kegiatan yang sedang berlangsung (Sukmadinata, 2007:220). Observasi dilakukan untuk mengetahui perilaku siswa selama proses pembelajaran baik yang berkaitan dengan a) keberanian, b) Kelancaran Berbicara, c) Gaya lagu/kalimat, d) Percaya diri, dan e) Keleluasaan materi.

Analisis Data keabsahan data merupakan salah satu langkah awal kebenaran dari analisis data. Dalam menguji keabsahan suatu data atau memeriksa kebenaran data digunakan cara memperpanjang masa penelitian, pengawasan yang terus-menerus, triangulasi teknik pengumpulan data, menganalisis kasus negatif, mengadakan sumber check, serta membicarakan dengan orang lain atau teman sejawat. Menurut Sukmadinata (2007: 153), validitas menunjukkan ketepatan pengumpulan data, atau data yang dikumpulkan memang benar-benar yang ingin diperoleh peneliti. Validitas pengumpulan data kualitatif meliputi 2 hal yaitu keterpercayaan dan keterpahaman.

\section{HASIL PENELITIAN}

\section{Siklus I}

Pada siklus I ini guru memberikan tindakan pembelajaran dengan menggunakan Media gambar fauna pada styrofoam yang dibuat menggunakan alat bantu sablon manual. Sasaran pokok dalam penerapan media ini adalah upaya meningkatkan keterampilan berbicara siswa tunagrahita kelas VIII C1 di SLBN 1 Kota Blitar. Langkah kegiatan pada siklus I adalah sebagai berikut : 
Perencanaan menyiapkan RPP sebagai pedoman rencana kegiatan yang telah dibuat Menyiapkan materi Menyiapkan Lembar Observasi. Pelaksanaan Tindakan guru memberikan materi mengenal fauna dengan media gambar styrofoam disertai dengan penugasan, Siswa memperhatikan penjelasan guru, Guru melakukan demonstrasi membuat media gambar fauna dari styrofoam yang dibuat menggunakan alat bantu sablon manual dan menjelaskan materi selanjutnya meminta siswa kelas VIII C1 SLBN I Kota Blitar untuk memperhatikan guru dan Guru memberikan tes kepada siswa mengenai materi mengenal fauna. Observasi Dari 3 siswa, 2 siswa (66 \%) menunjukkan kategori kemampuan siswa rata-rata cukup dan 1 siswa (33\%) siswa menunjukkan kategori baik, dari seluruh aspek pengamatan dalam penelitian yang telah ditetapkan Penilaian hasil pada Siklus ini juga dilaksanakan, namun baru sebatas untuk mengetahui sejauh mana pengaruh media gambar terhadap keterampilan berbicara. Hal ini dibuktikan dengan hasil proses dan hasil nilai tentang proses kegiatan pembelajaran berbicara setelah menggunakan media gambar pada Silkus I ini.

Tabel 1. Nilai Pengamatan Siswa Kelas VIII C1 SLBN 1 Kota Blitar pada Siklus I

\begin{tabular}{cccccccc}
\hline \multirow{2}{*}{ No. } & Nama & Keberanian & $\begin{array}{c}\text { Kelancaran } \\
\text { Berbicara }\end{array}$ & $\begin{array}{c}\text { Gaya/ lagu } \\
\text { kalimat }\end{array}$ & $\begin{array}{c}\text { Percaya } \\
\text { diri }\end{array}$ & $\begin{array}{c}\text { Keluluasaan } \\
\text { materi }\end{array}$ & Jumlah \\
\hline 1. & Afandi & 16 & 16 & 14 & 16 & 14 & 76 \\
2. & Indah & 14 & 13 & 13 & 12 & 14 & 66 \\
3. & Putri & 15 & 14 & 14 & 13 & 15 & 71 \\
\hline \multicolumn{7}{c}{$\begin{array}{c}\text { Total } \\
\text { Rata-rata }\end{array}$} \\
\hline
\end{tabular}

\begin{tabular}{cllrrrrc}
\hline No. & Kategori & Interval & X & F & $\mathbf{f ( x )}$ & $\mathbf{\%}$ & Ket \\
\hline 1. & Amat baik & $90-100$ & 95 & 0 & 0 & 0 & $216 / 3=72$ \\
2. & Baik & $75-89$ & 82 & 1 & 82 & 37,96 & \\
3. & Cukup & $60-74$ & 67 & 2 & 134 & 62,04 & \\
4. & Kurang & $\leq 59$ & 45 & 0 & 0 & 0 & \\
\hline \multicolumn{2}{c}{ Jumlah } & & 3 & 216 & 100 & (Cukup) \\
\hline
\end{tabular}

Refleksi Dari tabel tersebut dapat dijelaskan bahwa ada sedikit peningkatan pada Siklus I dibanding dengan hasil nilai sebelum Penelitian Tindakan Kelas dilaksanakan. Nilai siswa sudah ada peningkatan namun masih relative kecil presentasinya. Hasil menunjukkan bahwa dari 3 siswa 2 siswa (66 \%) belum mencapai batas tuntas, hanya 1 siswa (33 \%) dari 3 siswa telah mencapai batas tuntas (KKM) yang telah ditetapkan. Jadi ada peningkatan sejumlah $33 \%$, itu belum merupakan angka yang menggembirakan., karena masih ada siswa yang nilainya masih dibawah KKM yakni 2 siswa (66 \%). Diharapkan terus ada peningkatan pada Siklus berikutnya.

Tabel 2. Nilai Keterampilan Berbicara Siswa Kelas VIII C1

SLBN 1 Kota Blitar pada Siklus I

\begin{tabular}{|c|c|c|c|c|c|c|c|c|}
\hline \multirow[b]{2}{*}{ No. } & \multirow[b]{2}{*}{ Nama } & \multicolumn{7}{|c|}{ Aspek yang dinilai } \\
\hline & & $\begin{array}{c}\text { Kesesuaian ide } \\
\text { dengan isi }\end{array}$ & $\begin{array}{c}\text { Kejelasan } \\
\text { suara }\end{array}$ & Lafal & Ekspresi & $\begin{array}{c}\text { Struktur } \\
\text { kalimat }\end{array}$ & Jumlah & Nilai \\
\hline 1. & Afandi & 8 & 8 & 8 & 8 & 8 & 40 & 80 \\
\hline 2. & Indah & 6 & 7 & 6 & 7 & 6 & 32 & 64 \\
\hline 3. & Putri & 7 & 7 & 7 & 7 & 7 & 35 & 70 \\
\hline & \multicolumn{7}{|c|}{ Jumlah } & 212 \\
\hline & \multicolumn{7}{|c|}{ Rata-rata } & 70,66 \\
\hline
\end{tabular}

\section{Siklus II}

Siklus II merupakan perbaikan dari kelemahan siklus sebelumnya. Perencanaan kegiatan pada Siklus II adalah : Perencanaan guru menyiapkan RPP, bersama siswa menyiapkan media pembelajaran, menyiapkan lembar kegiatan siswa. Pelaksanaan Tindakan pada Siklus II merupakan tindakan perbaikan dari pelaksanaan tindakan pada Siklus I. Adapun pelaksanaan tindakan pada Siklus II sebagai berikut : Guru menjelaskan materi mengenal fauna, Guru memberikan contoh cara membuat media gambar fauna pada styrofoam yang dibuat menggunakan alat bantu sablon manual selanjutnya 
guru memberi kesempatan siswa untuk mencoba dan menjelaskan terkait materi mengenal fauna, Siswa saling bekerjasama dalam membuat media, Siswa mengamati teman yang membantu untuk membuat media dan mengisi lembar pengamatan yang ada. dan Siswa membuat kesimpulan bersamasama dan membacakannya di depan kelas dengan bimbingan guru. Observasi Dari 3 siswa, 3 siswa (100 \%) menunjukkan kategori kemampuan siswa rata-rata baik dan telah mencapai batas tuntas (KKM) yang telah ditetapkan. dari seluruh aspek pengamatan dalam penelitian yang telah ditetapkan. Pada kegiatan siklus II ini guru hanya sebagai pembimbing dan fasilitator serta motivator saja, sehingga tidak terlibat secara penuh dalam pembelajaran.

Tabel 3. Nilai Pengamatan Siswa Kelas VIII C1 SLBN 1 Kota Blitar pada Siklus II

\begin{tabular}{cccccccc}
\hline & & \multicolumn{5}{c}{ Aspek yang dinilai } \\
\cline { 3 - 7 } No. & Nama & Keberanian & $\begin{array}{c}\text { Kelancaran } \\
\text { Berbicara }\end{array}$ & $\begin{array}{c}\text { Gaya/ lagu } \\
\text { kalimat }\end{array}$ & $\begin{array}{c}\text { Percaya } \\
\text { diri }\end{array}$ & $\begin{array}{c}\text { Keluluasaan } \\
\text { materi }\end{array}$ & Jumlah \\
\hline 1. & Afandi & 17 & 16 & 16 & 16 & 18 & 83 \\
2. & Indah & 16 & 7 & 15 & 16 & 16 & 80 \\
3. & Putri & 17 & 16 & 18 & 16 & 15 & 82 \\
\hline \multicolumn{7}{c}{$\begin{array}{c}\text { Total } \\
\text { Rata-rata }\end{array}$} \\
\hline
\end{tabular}

\begin{tabular}{cllrrrrc}
\hline No. & Kategori & Interval & X & F & $\mathbf{f ( x )}$ & $\mathbf{\%}$ & Ket \\
\hline 1. & Amat baik & $90-100$ & 95 & 0 & 0 & 0 & $246 / 3=82$ \\
2. & Baik & $75-89$ & 82 & 3 & 246 & 100 & \\
3. & Cukup & $60-74$ & 67 & 0 & 0 & 0 & \\
4. & Kurang & $\leq 59$ & 45 & 0 & 0 & 0 & \\
\hline \multicolumn{2}{c}{ Jumlah } & & 3 & 246 & 100 & (Baik) \\
\hline
\end{tabular}

Refleksi dari tabel tersebut dapat dijelaskan bahwa ada peningkatan yang sangat signifikan pada Siklus II dibanding dengan hasil nilai pada siklus I. Semakin hari semakin menggembirakan dengan hasil pembelajaran keterampilan berbicara yang menjadi fokus peneliti ini. Hasilnya menunjukkan bahwa dari 3 siswa (100 \%) nilainya mencapai batas Kriteria Ketuntasan Minimal (KKM), yang sebelumnya pada Siklus I siswa yang mencapai batas tuntas baru 33 \% (1 siswa). Dengan demikian dapat dikatakan pelaksanaan tindakan penelitian ini dapat berhasil meningkat keterampilan berbicara siswa dengan satu alat bantu yaitu media gambar styrofoam.

Tabel 4. Nilai Keterampilan Berbicara Siswa Kelas VIII C1

SLBN 1 Kota Blitar pada Siklus II

\begin{tabular}{|c|c|c|c|c|c|c|c|c|}
\hline \multirow[b]{2}{*}{ No. } & \multirow[b]{2}{*}{ Nama } & \multicolumn{7}{|c|}{ Aspek yang dinilai } \\
\hline & & $\begin{array}{c}\text { Kesesuaian ide } \\
\text { dengan isi }\end{array}$ & $\begin{array}{c}\text { Kejelasan } \\
\text { suara }\end{array}$ & Lafal & Ekspresi & $\begin{array}{l}\text { Struktur } \\
\text { kalimat }\end{array}$ & Jumlah & Nilai \\
\hline 1. & Afandi & 9 & 8 & 8 & 9 & 8 & 42 & 84 \\
\hline 2. & Indah & 8 & 8 & 7 & 8 & 8 & 39 & 78 \\
\hline 3. & Putri & 8 & 7 & 9 & 8 & 8 & 40 & 80 \\
\hline \multicolumn{8}{|c|}{ Jumlah } & $\begin{array}{c}242 \\
80,66\end{array}$ \\
\hline
\end{tabular}

\section{SIMPULAN DAN SARAN}

\section{Simpulan}

Penerapan media gambar styrofoam pada pembelajaran Bahasa Indonesia dapat meningkatkan keterampilan berbicara siswa kelas VIII C1 semester I di SLBN 1 Kota Blitar dalam mendeskripsikan mengenal fauna atau lainnya. Bukti dari peningkatan kemampuan siswa tersebut dapat dilihat pada peningkatan nilai rata-rata siswa dalam belajar yaitu pada kondisi awal diperoleh rata-rata ulangan 31,33, pada siklus I diperoleh rata-rata 70,65 dan pada siklus II diperoleh rata-rata 81,66 
Aktivitas siswa dalam belajar juga mengalami peningkatan yaitu semua siswa melakukan kegiatan pembelajaran dalam membuat media gambar secara bergantian, bertanya jika kurang paham dengan kegiatan, menjawab pertanyaan yang diajukan guru ataupun menyatakan gagasan sederhana. Motivasi yang diberikan guru memberikan semangat bagi siswa dalam melakukan kegiatan pembelajaran sehingga tercipta pembelajaran yang aktif, kreatif, efektif dan menyenangkan bagi siswa. Selain itu kegiatan pembelajaran memudahkan siswa dalam memahami materi mengenal fauna. Saran

Guru perlu meningkatkan sikap siswa terhadap pembelajaran keterampilan berbicara agar siswa tidak merasa takut, malu, tidak bersemangat dalam melakukan kegiatan berbicara di depan guru maupun teman-temannya, dengan memberikan metode pembelajaran yang bervariasi. Dengan media atau metode pembelajaran yang bervariasi akan merangsang siswa untuk berkomunikasi secara optimal dalam pembelajaran.

\section{DAFTAR PUSTAKA}

Abdul Majid dan Dian Andayani, 2004. Pendidikan Agama Islam Berbasis Kompetensi, Bandung; Remaja Rosdakarya.

Ahmad, 2005. Ideologi Pendidikan Islam, Yogyakarta: Pustaka Pelajar.

Aqib,Z dan Elham.R. 2007. Membangun Profesionalisme Guru dan Pengawas Sekolah. Lamongan : Yrama Widya.

Arikunto.S., 2006. Prosedur Penelitian Suatu Pendekatan Praktik. Rineka Cipta-Jakarta

Depdikbud. 2001. Kamus Besar Bahasa Indonesia, Jakarta : Depdikbud.

Fatturrahman. 2006. Metode Demonstrasi dan Eksperimen. Diakses dari www.google.com tanggal 2 Agustus 2019.

Hurruhman, F. 2008. Demonstrasi dan Eksperimen. http://udhiexz.wordpress .com/2008/08/08/metode-demonstrasi-dan-eksperimen/Metode Demonstrasi dan Eksperimen. Diakses tanggal 2 Agustus 2018.

Irpan Abd. Gafar \& Muhammad Jamil, 2003. Reformulasi Rancangan Pembelajaran Pendidikan Agama Islam. Jakarta: Raja Grafindo.

Iskandar. 2004. Pembelajaran Ilmu pengetahuan Alam. Bandung: Remaja Rosda Karya

Iskandarwassid \& Dadang Sunendar. (2011). Strategi Pembelajaran Bahasa. Bandung: PT Remaja Rosdakarya.

Marwoto. 1995. Teori dan Apresiasi Sastra. Yogyakarta. Pustaka Pelajar.

Miles, M.B dan Hubermann, A.M. 1992. Analisis Data Kualitatif. Jakarta : Universitas Indonesia Press

Moh. Amin. 1995. Ortopedagogik Anak Tunagrahita. Bandung: Jemars

Muhammad Alim, 2006. Pendidikan Agama Islam Upaya Pembentukan Pemikiran dan Kepribadian Muslim, Bandung; Remaja Rosdakarya.

Mulyasa,E. 2006. Menjadi Guru Profesional. Bandung : Remaja Rosdakarya

Munadi, Yudi. 2008. Media Pembelajaran. Jakarta : Gaung Persada Press.

Nurgiyanto. 2000. Penelitian dalam Pengajaran Bahasa dan Sastra, BPFE, Yogyakarta.

Penyebab Gangguan Bicara Dan Bahasa 2. Diakses dari: http://speechclinic.wordpress.com. Pada tanggal 15 September 2019, Jam 16.32 WIB.

Peter Salim \& Tenny Salim. 1991. Kamus Bahasa Indonesia Kontemporer. Jakarta: Modern English

Popshan, James. W. 1995. Clasrom Assassement What Teacher Need to Know. Los Angles : University of California.

Rochiati Wiriatmadja. 2005. Metode Penelitian Tindakan Kelas. Bandung: Remaja Rosda Karya

Sanjaya,W. 2008. Perencanaan dan Desain Sistem Pembelajaran. Jakarta : Kencana

Sarwiji Suwandi. 2004. "Penerapan Pendekatan Kontekstual dalam Mengimplementasikan Kurikulum Berbasis Kompetensi.” Retikorika Vol.2 No.2 Maret 2004. Surakarta: UNS.

Subiantoro. 2003. Metode Menyanyi dan Bercerita pada Anak Usia Pra Sekolah. Jakarta: Dirjen PADU.

Suhartono. (2005). Pengembangan Keterampilan Berbicara Anak Usia Dini. Jakarta: Depdiknas.

Sudirman, dkk. 1992. Ilmu Pengetahuan. Bandung:Remaja Rosdakarya

Sukmadinata, Nana Syaodih. 2007. Metode Penlitian Pendidikan. Bandung: PT. Remaja Rosdakarya

Sutratinah Tirtonegoro. 2001. Anak Supernormal dan Program Pendidikannya. Jakarta: Bina Aksara 
Tarigan, HG. (2008). Berbicara (Sebagai Suatu Keterampilan Berbahasa. Bandung: Angkasa. W. Gulo. 2003. Metodologi Penelitian. Jakarta : Grasindo

Yamin, Martinus. 2008. Profesionalisasi Guru dan Implementasi KTSP. Jakarta : Gaung Persada Press Zulkarnaeni. 2005. Penelitian Tindaka Kelas Informasi Sederhana Pengembangan Profesi. Diakses dari www.google.com pada Agustus 2019.

\section{PROFIL SINGKAT}

Eko Julianto Wibowo seorang guru yang mengajar di SLBN 1 Kota Blitar Jawa Timur, lahir di Surabaya 30 Juli 1986 berhobi sepak bola, futsal, voli dan renang yang mempunyai prinsip rajin kerja tanpa diawasi. Pendidikan S1 Pendidikan Luar Biasa di Universitas Negeri Surabaya UNESA pada tahun 2005-2009 kemudian mendapatkan beasiswa dari Pembinaan Pendidik Dan Tenaga Kependidikan Pendidikan Dasar (P2TK) Kementerian Pendidikan Dan Kebudayaan S2 kebetulan juga di Pascasarjana Pendidikan Luar Biasa di Universitas Negeri Surabaya UNESA pada tahun 20142016. Aktivitas yang dilakukan sampai saat ini mengajar di SLBN 1 Kota Blitar Jawa Timur dan mencoba banyak hal melakukan aktifitas positif serta menginginkan agar hidup saya selalu bermanfaat dimanapun baik dikeluarga, sekolahan, dan masyarakat lebih luasnya NKRI yang tercinta ini sehingga menjadi orang yang beruntung dunia akhirat adalah impiannya, berguna bagi masyarakat adalah harapan saya, dan Beribadah adalah tujuan hidup saya. 